\title{
ARSENATE-INDUCED TOXICITY: EFFECTS ON ANTIOXIDATIVE ENZYMES AND DNA DAMAGE IN VICIA FABA
}

\author{
Aijun Lin, $\dagger+$ Xuhong Zhang, $\S$ Yong-Guan Zhu, $* \neq$ and Fang-Jie Zhao\# \\ †Department of Environmental Science and Engineering, Beijing University of Chemical Technology, Beijing 100029, \\ People's Republic of China \\ $¥$ State Key Lab of Regional and Urban Ecology/Department of Soil Environmental Sciences, Research Center for Eco-Environmental \\ Sciences, Chinese Academy of Sciences, Beijing 100085, People's Republic of China \\ $\S$ Beijing City University, Beijing 100083, People's Republic of China \\ Institute of Urban Environment, Chinese Academy of Sciences, Xiamen 361003, People's Republic of China \\ \#Agriculture and the Environment Division, Rothamsted Research, Harpenden, Herts AL5 2JQ, United Kingdom
}

(Received 19 April 2007; Accepted 6 August 2007)

\begin{abstract}
A glasshouse hydroponic experiment was conducted to investigate the toxicity of arsenate to broad bean (Vicia faba) plants when grown with external arsenate concentrations at $10 \mu \mathrm{mol} / \mathrm{L}$. The treated plants showed no obvious symptoms of phytotoxicity, but shoot/root growth was inhibited. Lipid peroxidation in leaves and roots increased with the addition of arsenate, indicating oxidative stress. We investigated the responses to arsenate exposure in the activities of several representative antioxidant enzymes, including peroxidase (POD), catalase (CAT), and superoxide dismutase (SOD), in plant tissues, and the DNA damage in plant leaves and root tips induced by arsenate in this plant was detected for the first time. Arsenate addition increased POD activity in the leaves significantly but decreased its activity in the roots in the $10 \mu \mathrm{mol} / \mathrm{L}$ treatment. Arsenate addition caused an induction of SOD and CAT activities in both leaves and roots, but not in roots at the arsenate concentration of $10 \mu \mathrm{mol} / \mathrm{L}$. The DNA damage in $V$. faba was detected using Comet assay; in both leaves and roots, DNA damage increased with increasing arsenate concentrations, indicating genotoxicity of arsenate. These results indicate that arsenate toxicity causes oxidative stress in $V$. faba, which might be one of the mechanisms through which arsenic induces DNA damage.
\end{abstract}

Keywords-Arsenate Vicia faba Oxidative stress DNA damage

\section{INTRODUCTION}

Arsenic is a metalloid frequently found in soils, water, and air, and its presence in the environment results from both natural and anthropogenic sources [1]. Major anthropogenic sources of As are metal processing, coal burning, and application of As-based pesticides or herbicides [2]. Inorganic arsenate and arsenite are the chemical forms most commonly detected in the environment, with arsenate and arsenite being the predominant form under anaerobic and aerobic conditions, respectively [3]. Some microorganisms can transform these compounds by oxidation/reduction or methylation/demethylation reactions [2,3]. Recently, public concern regarding this element has been increasing, because As may be toxic even at low concentrations [1]. Arsenic is highly toxic to plants and animals and may accumulate in plants, not only affecting plant growth but also entering the food chain, posing potential health risks to humans.

Arsenic is known to produce mutagenic and genotoxic effects on humans, causing, for example, lung, skin, and bladder cancers [4,5]. Kitchin [6] reviewed the mechanisms of As carcinogenesis and found evidence for three modes of action both in experimental systems (animal and human cells) and in human tissues: Chromosomal abnormalities, oxidative stress, and a continuum of altered growth factors leading to cell proliferation and promotion of carcinogenesis. Using the method of single-cell gel electrophoresis, or the Comet assay,

* To whom correspondence may be addressed (ygzhu@mail.rcees.ac.cn).

Published on the Web 10/08/2007. it was demonstrated that arsenite and dimethylarsinic acid induced DNA damage and DNA cross-linking in human cells [4]. Plants are one of the important components of natural and managed ecosystems; however, few studies have examined Asinduced DNA damage and the underlying mechanisms in plants. In the past, many studies focused on the physiological effects, such as the inhibition of plant growth by As and the mechanisms of As resistance employed by plants [7]. It has been shown that As exposure leads to an overproduction of reactive oxygen species (ROS) or suppressed activities of enzymatic antioxidants in plant tissues, inducing oxidative stress [8-13]. Whether the oxidative stress induced by As exposure would lead to DNA damage in plants has not been investigated. Therefore, the aim of the present study was to evaluate the toxicity of arsenate, particularly oxidative stress and DNA damage in plant cells.

\section{MATERIALS AND METHODS}

\section{Chemicals and reagents}

All chemicals were of reagent grade and purchased from Sigma Chemical (Beijing, China) or Beijing Chemical (Beijing, China).

\section{Plant materials and treatments}

Seeds of Vicia faba, purchased from Huazhong Normal University (Wuhan, Hubei Province, China), were sterilized in $70 \%$ (v/v) ethanol for $10 \mathrm{~min}$. The seeds were washed with tap water and redistilled water, then sown in vermiculite in plastic pots. Fourteen days after germination, the seedlings were used in the experiments. The vermiculite was washed 
from the root system with tap water, and the roots were rinsed with redistilled water. Uniform seedlings were transferred to hydroponic pots, each containing $500 \mathrm{ml}$ of nutrient solution. The modified Hoagland-Arnon nutrient solution [14,15] was used as the growth medium, and the composition of the nutrient solution was $1,000 \mu \mathrm{mol} / \mathrm{L}$ of $\mathrm{KNO}_{3}, 1,000 \mu \mathrm{mol} / \mathrm{L}$ of $\mathrm{Ca}\left(\mathrm{NO}_{3}\right)_{2}, 400 \mu \mathrm{mol} / \mathrm{L}$ of $\mathrm{MgSO}_{4} \cdot 7 \mathrm{H}_{2} \mathrm{O}, 150 \mu \mathrm{mol} / \mathrm{L}$ of $\mathrm{KH}_{2} \mathrm{PO}_{4}, 2.5 \mu \mathrm{mol} / \mathrm{L}$ of $\mathrm{MnSO}_{4}, 0.5 \mu \mathrm{mol} / \mathrm{L}$ of $\mathrm{ZnSO}_{4}, 50$ $\mu \mathrm{mol} / \mathrm{L}$ of $\mathrm{Fe}-\mathrm{ethylenediaminetetra-acetic} \mathrm{acid} \mathrm{(EDTA),} 0.5$ $\mu \mathrm{mol} / \mathrm{L}$ of $\mathrm{CuSO}_{4} \cdot 5 \mathrm{H}_{2} \mathrm{O}, 5.0 \mu \mathrm{mol} / \mathrm{L}$ of $\mathrm{HBO}_{3}, 0.25 \mu \mathrm{mol} / \mathrm{L}$ of $\mathrm{Na}_{2} \mathrm{MoO}_{4}, 0.1 \mu \mathrm{mol} / \mathrm{L}$ of $\mathrm{CoSO}_{4}$, and $50 \mu \mathrm{mol} / \mathrm{L}$ of $\mathrm{NaCl}$. Plants were cultivated in a controlled-environment growth chamber at $25^{\circ} \mathrm{C}$ with a $14: 8$-h light:dark photoperiod with a light intensity of $350 \mu \mathrm{mol} /\left(\mathrm{m}^{2} \cdot \mathrm{s}\right)$ and $70 \%$ relative humidity. After $28 \mathrm{~d}$ of growth in hydroponic culture, plants were treated with different concentrations of arsenate for $14 \mathrm{~d}$. The arsenate concentrations tested were 0 (control), 5, and $10 \mu \mathrm{mol} / \mathrm{L}$ supplied as $\mathrm{Na}_{2} \mathrm{HAsO}_{4}$. Each treatment had four replicates. The nutrient solution was continuously aerated using air pumps and was replaced every $2 \mathrm{~d}$.

\section{Plant harvest and As analysis}

After being treated for $14 \mathrm{~d}$, the plants were harvested. Roots, stems, and leaves were separated and washed with redistilled water, and the fresh weights were determined. Roots and leaves were divided into three subsamples. Subsamples of leaves and root tips were used in the Comet assay and approximately $1.0 \mathrm{~g}$ (fresh $\mathrm{wt}$ ) of roots or leaves in the enzymatic analyses; the remainders were dried $\left(55^{\circ} \mathrm{C}\right.$ for $\left.72 \mathrm{~h}\right)$ to determine the dry weights and As concentrations. The dried plant tissues were ground in a stainless-steel mill and digested with concentrated $\mathrm{HNO}_{3}$. Temperature during digestion was controlled at a maximum of 120 to $130^{\circ} \mathrm{C}$ to avoid volatilization of As [16]. Digested samples were filtered and diluted with redistilled water to $25 \mathrm{ml}$. The As concentration was determined by inductively coupled plasma-optical emission spectroscopy (Optima 2000 DV; PerkinElmer, Shelton, CT, USA). Acid blanks were included to assess possible As contamination. A standard plant material (GBW07603) from the Department of Earth and Mine, Beijing, China, was used to verify the accuracy of As determination. The recovery rates for As was within $90 \pm 10 \%$. The As concentration of the $\mathrm{HNO}_{3}$ used was less than the detection limit of the inductively coupled plasma-optical emission spectroscopy $(0.05 \mathrm{mg} / \mathrm{L})$.

\section{Estimation of lipid peroxidation}

Lipid peroxidation was estimated following the method described by Verma and Dubey [17]. Fresh samples of roots or leaves $(\sim 200 \mathrm{mg})$ were ground in $0.25 \%$ thiobarbituric acid (TBA) in $10 \%$ trichloroacetic acid with a mortar and pestle. The mixtures were heated at $95^{\circ} \mathrm{C}$ for $30 \mathrm{~min}$, cooled quickly in an ice bath, and centrifuged at $10,000 \mathrm{~g}$ for $10 \mathrm{~min}$. The absorbance of the supernatant was recorded at $532 \mathrm{~nm}$ and corrected for unspecific absorbance by subtracting the absorbance at $600 \mathrm{~nm}$. The solution of $0.25 \%$ TBA in $10 \%$ trichloroacetic acid served as a blank. Thiobarbituric acid-reactive substances (TBARS) were expressed as nmol/g fresh weight using an extinction coefficient of $155 \mathrm{mmol} / \mathrm{L} / \mathrm{cm}$.

\section{Enzyme extractions}

Fresh root and leaf samples ( $\sim 500 \mathrm{mg}$ ) were ground in liquid nitrogen using a mortar and pestle. The ground samples were homogenized on ice in $10 \mathrm{ml}$ of solution containing 50 $\mathrm{mmol} / \mathrm{L}$ of potassium phosphate buffer and $1 \%(\mathrm{w} / \mathrm{v})$ polyvinylpyrrolidone $\left(\mathrm{pH} \mathrm{7.8)}\right.$ and kept at $4^{\circ} \mathrm{C}$ for $10 \mathrm{~min}$. The homogenates were filtered and centrifuged at 4,000 $\mathrm{g}$ for 15 $\min$ at $4^{\circ} \mathrm{C}$. The supernatants were used for further analyses.

\section{Peroxidase assay}

The peroxidase (POD) activity was determined at $25^{\circ} \mathrm{C}$ with guaiacol [18]. In the presence of $\mathrm{H}_{2} \mathrm{O}_{2}$, POD catalyzes the transformation of guaiacol to tetraguaiacol (a brown product). The increase in absorbance was measured at $470 \mathrm{~nm}$ at $30-\mathrm{s}$ intervals for up to $2 \mathrm{~min}$ using a spectrophotometer (Ultraviolet-3010; Shimadzu, Tokyo, Japan). The reaction mixture contained $100 \mathrm{mmol} / \mathrm{L}$ of potassium phosphate buffer ( $\mathrm{pH} 6.0$ ), $33 \mathrm{mmol} / \mathrm{L}$ of guaiacol, and $0.3 \mathrm{mmol} / \mathrm{L}$ of $\mathrm{H}_{2} \mathrm{O}_{2}$.

\section{Superoxide dismutase assay}

The activities of superoxide dismutase (SOD) were determined using the published method for photoreduction of nitroblue tetrazolium chloride (NBT) with some modifications $[9,19]$. The assay mixture at a total volume of $3 \mathrm{ml}$ in a $5-\mathrm{ml}$ cuvette contained $13 \mathrm{mmol} / \mathrm{L}$ of methionine, $10 \mu \mathrm{mol} / \mathrm{L}$ of riboflavin, $75 \mu \mathrm{mol} / \mathrm{L}$ of NBT, $10 \mu \mathrm{mol} / \mathrm{L}$ of EDTA, 0.05 $\mathrm{mol} / \mathrm{L}$ of phosphate buffer ( $\mathrm{pH} 7.8)$, and enzyme extracts. The blue color developed after illumination of the mixtures, and after $30 \mathrm{~min}$ of reaction, the absorbance at $560 \mathrm{~nm}$ was recorded in a spectrophotometer (Ultraviolet-3010). Reduction of NBT under illumination was measured with or without the addition of the enzyme extract, and the difference between the two measurements was used to calculate the activity of SOD. One unit of activity is the amount of protein required to inhibit $50 \%$ initial reduction of NBT under light.

\section{Catalase assay}

The catalase (CAT) activities in leaf and root tissues were determined according to the method described by Aravind and Prasad [9] with some modifications. The reaction medium consisted of $50 \mathrm{mmol} / \mathrm{L}$ of potassium phosphate buffer $(\mathrm{pH} 7.0)$ and $19 \mathrm{mmol} / \mathrm{L}$ of $\mathrm{H}_{2} \mathrm{O}_{2}$ in a final volume of $3 \mathrm{ml}$. The decrease in the absorbance of $\mathrm{H}_{2} \mathrm{O}_{2}$ was recorded at $240 \mathrm{~nm}$ for $2 \mathrm{~min}$ using a double-beam spectrophotometer (Ultraviolet-3010), and $50 \mathrm{mmol} / \mathrm{L}$ of potassium phosphate buffer $(\mathrm{pH} 7.0)$ was used as the blank.

\section{DNA damage in leaves and root tips}

The Comet assay was used to detect DNA damage in the leaves and root tips of $V$. faba induced by arsenate in the experiment. After harvest, leaves and root tips were washed three times with double-distilled water, then blotted dry with filter paper (Waterman, Maidston, UK). All operations were conducted under dim or yellow light to avoid DNA damage by light. Plant material was placed in a $60-\mathrm{mm}$ Petri dish on ice and covered with $250 \mu \mathrm{l}$ of cold, $1 \times$ phosphate buffer solution $\left(130 \mathrm{mmol} / \mathrm{L}\right.$ of $\mathrm{NaCl}, 7 \mathrm{mmol} / \mathrm{L}$ of $\mathrm{Na}_{2} \mathrm{HPO}_{4}, 3$ $\mathrm{mmol} / \mathrm{L}$ of $\mathrm{NaH}_{2} \mathrm{PO}_{4}$, and $50 \mathrm{mmol} / \mathrm{L}$ of EDTA; $\mathrm{pH} 7.5$ ). Each leaf or root tip was cut gently into pieces with a new razor blade. The pieces were washed in the buffer by repeated pipetting using a micropipette. The nuclei were released and collected in the buffer.

The nuclei suspension was used in the alkaline Comet assay, and the slides were prepared as described by Navarrete et al. [20] and Gichner et al. [21] with some modifications [22]. After preparation, the slides were put in freshly prepared, cold alkaline buffer $(300 \mathrm{mmol} / \mathrm{L}$ of $\mathrm{NaOH}$ and $1 \mathrm{mmol} / \mathrm{L}$ of 


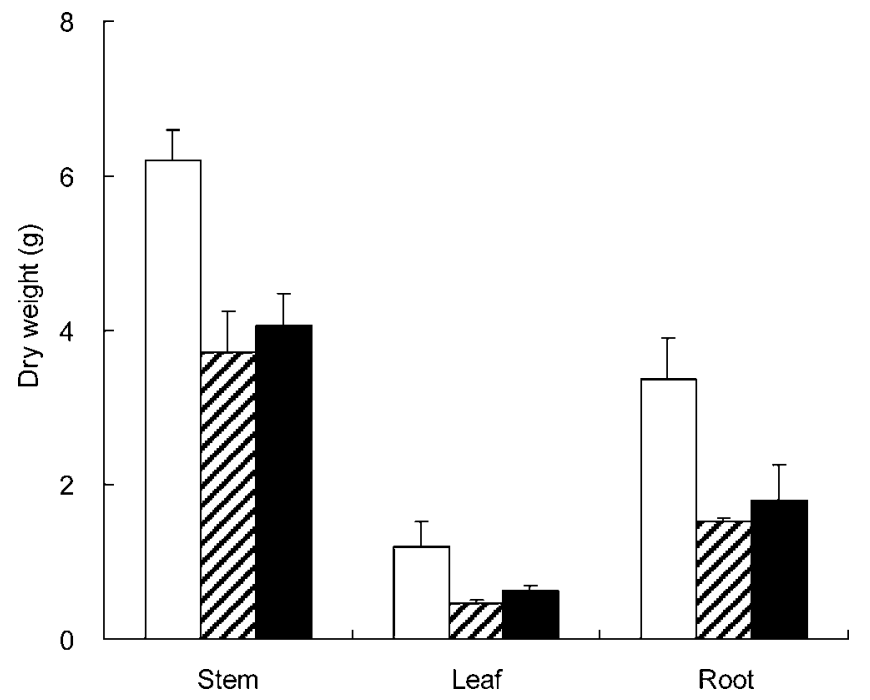

Fig. 1. Vicia faba plant biomass in dry weight $(\mathrm{g})$ for three different arsenate treatments. Data represent the mean \pm standard error $(n=$ 4). $\square=$ As, $0 \mu \mathrm{mol} / \mathrm{L}$ (control); $\square=$ As, $5 \mu \mathrm{mol} / \mathrm{L}$ treatment; $\square=$ As, $10 \mu \mathrm{mol} / \mathrm{L}$ treatment.

$\mathrm{Na}_{2}$ EDTA; $\mathrm{pH}>13$ ) at $4^{\circ} \mathrm{C}$ to allow the DNA to denature. Electrophoresis was then conducted at $4^{\circ} \mathrm{C}$ for $15 \mathrm{~min}$ at 300 $\mathrm{mA}$. After being neutralized with $0.4 \mathrm{~mol} / \mathrm{L}$ of Tris- $\mathrm{HCl}(\mathrm{pH}$ 7.5), each slide was stained with $50 \mu \mathrm{l}$ of $13 \mathrm{mg} / \mathrm{L}$ of ethidium bromide solution and viewed with a Zeiss Axioskop fluorescence microscope (Axioskop 2 Mot Plus; Zeiss, Jena, Germany) with an excitation filter of 510 to $560 \mathrm{~nm}$ and a barrier of $590 \mathrm{~nm}$. The Comet images were captured, and the imageanalysis system (CASP) was employed to measure various Comet parameters, including the tail length, tail DNA, tail moment (TM), and Olive tail moment (OTM) [23]. The tail length, as a rough estimate of the DNA migration, was recorded in arbitrary units. Tail DNA refers to the percentage of DNA in the Comet tail. Tail moment is the integrated value of DNA density in the tail multiplied by the migration distance. Olive tail moment is the product of the distance (in $x$ direction) between the center of gravity of the head and the center of gravity of the tail and the percentage of tail DNA. For each slide, 50 randomly chosen cells were analyzed for the values of tail length, tail DNA, TM, and OTM.

\section{Data analysis}

Means of four replicates and standard errors are presented. Analysis of variance was performed using the software Genstat $^{\circledR}$ for Windows ${ }^{\circledR}[24]$.

Table 1. As concentrations in plant tissue at different arsenate treatments ${ }^{\mathrm{a}}$

\begin{tabular}{lccc}
\hline $\begin{array}{l}\text { As concn. } \\
(\mu \mathrm{mol} / \mathrm{L})\end{array}$ & $\begin{array}{c}\text { Root } \\
(\mathrm{mg} / \mathrm{kg} \text { dry wt })\end{array}$ & $\begin{array}{c}\text { Stem } \\
(\mathrm{mg} / \mathrm{kg} \text { dry wt })\end{array}$ & $\begin{array}{c}\text { Leaf } \\
(\mathrm{mg} / \mathrm{kg} \text { dry wt })\end{array}$ \\
\hline 0 & - & - & - \\
5 & $33.17 \pm 2.94$ & $6.59 \pm 0.33$ & $6.27 \pm 1.39$ \\
10 & $94.24 \pm 6.61$ & $7.98 \pm 0.46$ & $7.81 \pm 0.72$ \\
\hline
\end{tabular}

a Values are presented as the mean \pm standard error. $-=$ below the detection limit of the inductively coupled plasma-optical emission spectroscopy $(2.5 \mathrm{mg} / \mathrm{L}$ of As).

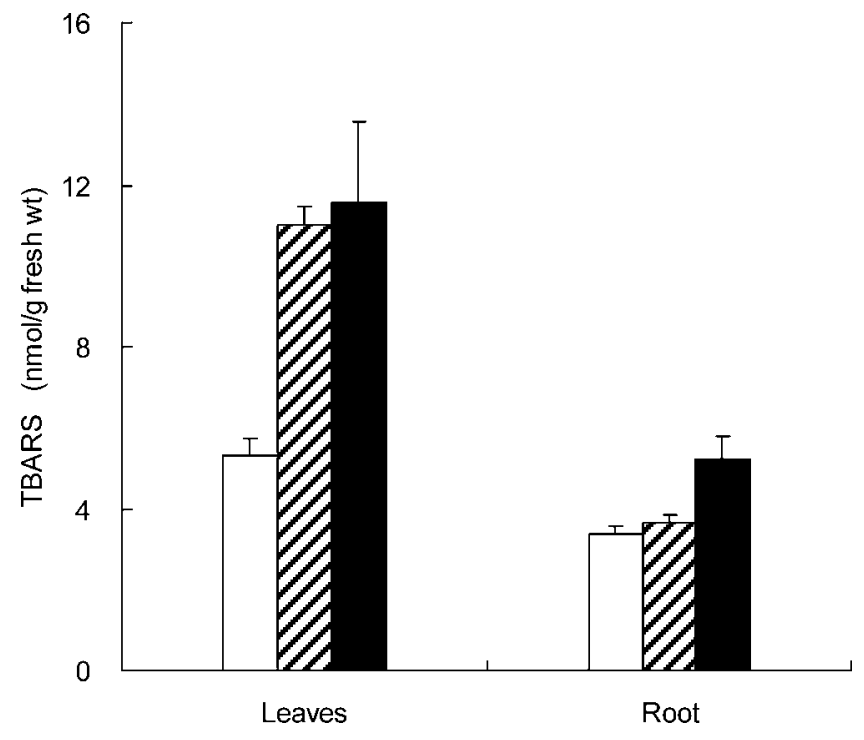

Fig. 2. Thiobarbituric acid-reactive substances (TBARS) in roots and leaves of Vicia faba under different arsenate addition. Data represent the mean \pm standard error $(n=4)$. $\square=$ As, $0 \mu \mathrm{mol} / \mathrm{L}$ (control); $\square$ $=$ As, $5 \mu \mathrm{mol} / \mathrm{L}$ treatment; $\boldsymbol{\square}=\mathrm{As}, 10 \mu \mathrm{mol} / \mathrm{L}$ treatment.

\section{RESULTS}

Effects of arsenate on growth of $\mathrm{V}$. faba

Compared with the control, the growth of $V$. faba was significantly $(p<0.05)$ inhibited by arsenate addition, but no significant difference was found between the two added arsenate concentrations (Fig. 1). The root elongation was inhibited, and the arsenate-treated roots, especially those in the 10 $\mu \mathrm{mol} / \mathrm{L}$ treatment, were shorter and thicker than those in the control.

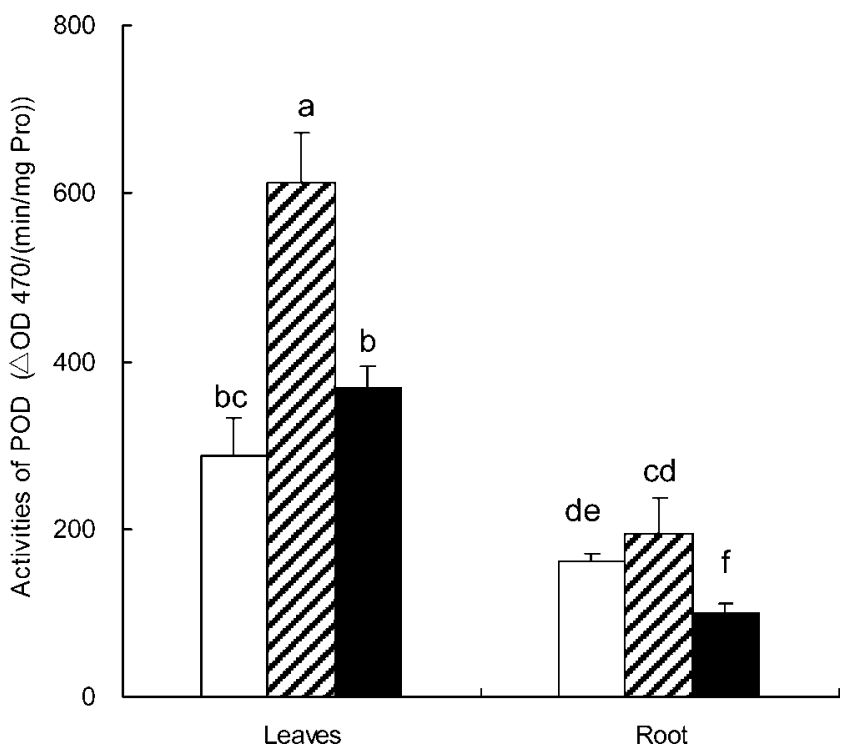

Fig. 3. Activities of peroxidase (POD) in roots and leaves of Vicia faba under different arsenate addition. Data represent the mean \pm standard error $(n=4)$. Different letters above columns indicate significant differences among different arsenate treatments as determined by least significant difference at the 5\% level. The changes in POD activities were represented by the changes in optical density at 470 $\mathrm{nm}$ (OD470). $\square=$ As, $0 \mu \mathrm{mol} / \mathrm{L}$ (control); $\square=$ As, $5 \mu \mathrm{mol} / \mathrm{L}$ treatment; $\mathbf{\square}=$ As, $10 \mu \mathrm{mol} / \mathrm{L}$ treatment. 


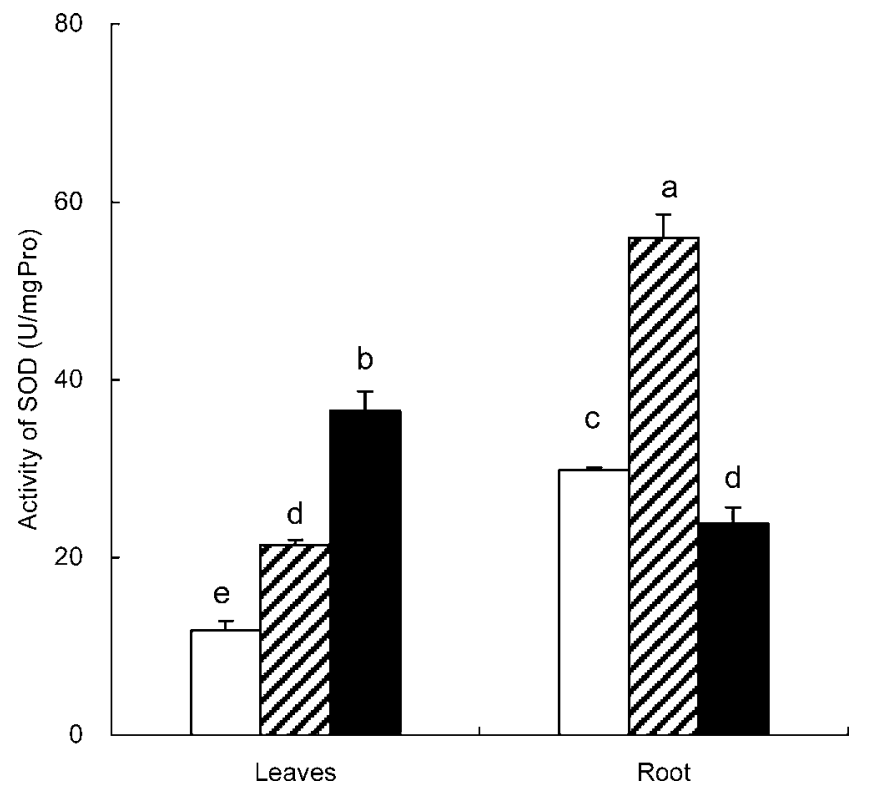

Fig. 4. Activities of superoxide dismutase (SOD) in Vicia faba plants treated with different concentrations of arsenate. Data represent the mean \pm standard error $(n=4)$. Different letters above columns indicate significant differences among different arsenate treatments as determined by least significant difference at the 5\% level. One unit (U) of activity is the amount of protein required to inhibit $50 \%$ initial reduction of nitroblue tetrazolium chloride under light. $\square=$ As, 0 $\mu \mathrm{mol} / \mathrm{L}$ (control); $\square=$ As, $5 \mu \mathrm{mol} / \mathrm{L}$ treatment; $\square=$ As, 10 $\mu \mathrm{mol} / \mathrm{L}$ treatment.

\section{Arsenic uptake}

The As concentrations in $V$. faba roots, stems, and leaves increased significantly $(p<0.05)$ with As addition in the culture solution (Table 1). Tissue As concentrations followed the trend roots $>$ stems and leaves, with most As being retained in the roots, especially in the treatment with high arsenate. In the leaves and stems, arsenate addition led to significant ( $p$ $<0.05)$ increases in As concentrations compared to the control, but no significant difference was found between the two arsenate treatments.

\section{Effect of arsenate on lipid peroxidation}

Lipid peroxidation in roots and leaves of $V$. faba, measured as TBARS, increased with increasing arsenate concentrations in the culture solution (Fig. 2). Arsenate addition led to significant increases in the TBARS level in leaves compared to the control $(p<0.05)$, but no significant difference was found between the treatments with 5 and $10 \mu \mathrm{mol} / \mathrm{L}$ of arsenate. Compared with the control, root TBARS level was significantly $(p<0.05)$ increased by the $10 \mu \mathrm{mol} / \mathrm{L}$ of arsenate treatment but not by the $5 \mu \mathrm{mol} / \mathrm{L}$ of arsenate treatment.

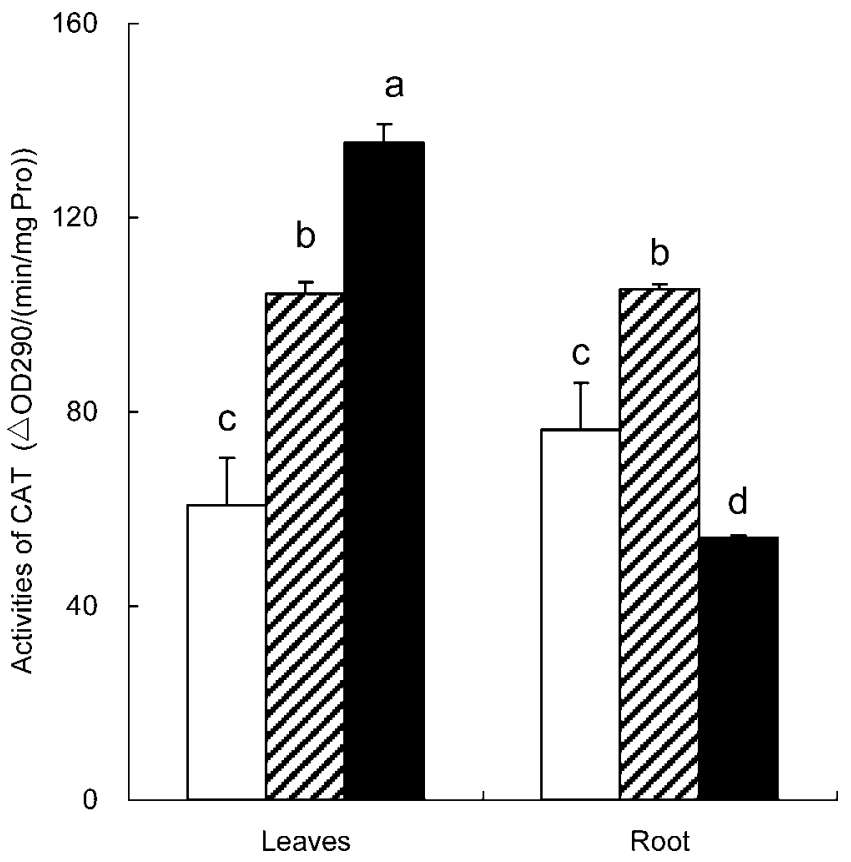

Fig. 5. Activities of catalase (CAT) in Vicia faba plants treated with different concentrations of arsenate. Data represent the mean \pm standard error $(n=4)$. Different letters above columns indicate significant differences among different arsenate treatments by least significant difference at the $5 \%$ level. The changes in CAT activities were represented by the changes in optical density at $290 \mathrm{~nm}$ (OD290). $\square=$ As, $0 \mu \mathrm{mol} / \mathrm{L}$ (control); $\square=$ As, $5 \mu \mathrm{mol} / \mathrm{L}$ treatment; $\square=$ As, 10 $\mu \mathrm{mol} / \mathrm{L}$ treatment.

\section{Effects of arsenate on activities of antioxidative enzymes}

$P O D$ activity. The activities of POD in the leaves and roots of $V$. faba are shown in Figure 3. In the leaves, the arsenate addition at $5 \mu \mathrm{mol} / \mathrm{L}$ increased the POD activity significantly $(p<0.05)$ compared with the control, but no significant difference was observed between the $10 \mu \mathrm{mol} / \mathrm{L}$ of arsenate treatment and the control. In the roots, no significant difference was found in POD activities between the control and the 5 $\mu \mathrm{mol} / \mathrm{L}$ of arsenate treatment, but arsenate addition at 10 $\mu \mathrm{mol} / \mathrm{L}$ led to a significant $(p<0.05)$ decrease in POD activity compared with the control.

SOD and CAT activities. The activities of SOD and CAT were affected by the arsenate treatments (Figs. 4 and 5). The activities of SOD and CAT in the leaves increased significantly $(p<0.05)$ with increasing arsenate concentration. In the roots, arsenate addition at $5 \mu \mathrm{mol} / \mathrm{L}$ increased SOD and CAT activities significantly $(p<0.05)$ compared with the control, but the $10 \mu \mathrm{mol} / \mathrm{L}$ of arsenate treatment led to a significant $(p<$ 0.05) decrease in SOD and CAT activities compared with the control.

Table 2. DNA damage in leaves of Vicia faba under different arsenate treatments ${ }^{\mathrm{a}}$

\begin{tabular}{lrcrc}
\hline & \multicolumn{4}{c}{ Parameters of DNA damage } \\
\cline { 2 - 5 } \begin{tabular}{l} 
As concentration \\
\cline { 2 - 2 }$/ \mathrm{L})$
\end{tabular} & Tail length $^{\mathrm{b}}$ & \% Tail DNA & TM & \multirow{2}{*}{ OTM } \\
\hline 0 & $41.6 \pm 9.6$ & $43.6 \pm 2.7$ & $22.8 \pm 5.6$ & $16.7 \pm 3.0$ \\
5 & $101.5 \pm 9.2$ & $75.6 \pm 1.8$ & $78.3 \pm 7.2$ & $46.4 \pm 4.8$ \\
10 & $120.8 \pm 4.4$ & $80.8 \pm 0.3$ & $99.3 \pm 2.3$ & $52.1 \pm 4.8$ \\
\hline
\end{tabular}

a Values are presented as the mean \pm standard error. $\mathrm{TM}=$ tail moment; OTM $=$ olive tail moment.

${ }^{\mathrm{b}}$ Relative length in arbitrary units. 

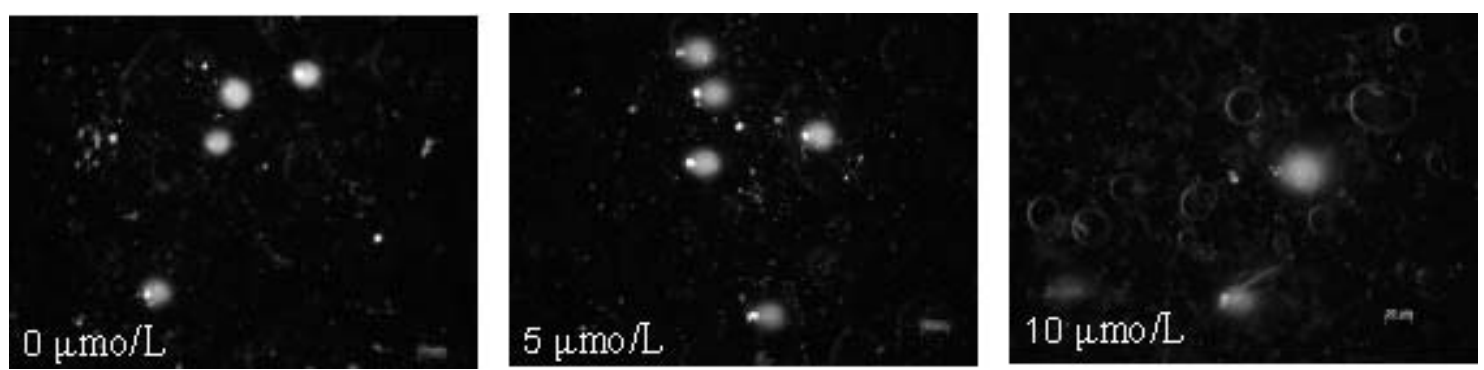

Fig. 6. Comet images of plant nuclei in the leaves of Vicia faba under arsenate treatments of 0,5 , and $10 \mu \mathrm{mol} / \mathrm{L}$.

\section{DNA damage}

The DNA migration in leaf and root tip samples increased with the addition of arsenate (Figs. 6 and 7). In both leaves and roots, the values of tail length, tail DNA, TM, and OTM were all significantly $(p<0.05)$ increased in both arsenate treatments compared with the control (Tables 2 and 3 ). In roots, the values of all Comet assay parameters were significantly higher at $10 \mu \mathrm{mol} / \mathrm{L}$ of arsenate compared with those at 5 $\mu \mathrm{mol} / \mathrm{L}$ of arsenate. In leaves, the values of tail length and TM were significantly higher at $10 \mu \mathrm{mol} / \mathrm{L}$ of arsenate compared with those at $5 \mu \mathrm{mol} / \mathrm{L}$ of arsenate.

\section{DISCUSSION}

Arsenic is phytotoxic and is expected to negatively affect plant growth [7]. Under the present experimental conditions, $V$. faba exposed to two concentrations of arsenate showed biomass reduction (Fig. 1) and inhibition of root elongation. The toxicity threshold for As differs between plants but usually is within the range of 5 to $100 \mathrm{mg} / \mathrm{kg}$ in shoots for nonhyperaccumulating plants [25]. The concentrations of As in leaves and stems of $V$. faba in the present experiment were only slightly greater than $5 \mathrm{mg} / \mathrm{kg}$ (Table 1 ), suggesting that the plants were stressed with only a mild degree of As toxicity, and more severe symptoms of phytotoxicity, such as necrosis, were not observed in the present experiment.

Heavy metal and metalloid toxicity is considered to induce the overproduction of ROS (e.g., $\mathrm{O}_{2}^{-}$and $\mathrm{H}_{2} \mathrm{O}_{2}$ ) and may result in significant oxidative damage to cellular constituents, such as DNA, proteins, and lipids [13]. Membrane lipids are especially prone to attack by free radicals, and lipid peroxidation is one of the main manifestations of oxidative damage [26]. In the present study, an increase in the level of TBARS in the leaves and roots of $V$. faba with arsenate addition indicated that the lipid peroxidation occurred in the tissues of $V$. faba in response to arsenate, which is consistent with a previous study using Holcus lanatus L. [8]. It is suggested that ROS may be generated through the conversion of arsenate to arsenite $[8,27]$.
High levels of lipid peroxidation might be expected to correspond with high levels of SOD activity [8]. Plants are protected against the oxidative stress by the operation of intricate antioxidative systems, comprising both enzymatic systems, such as SOD, ascorbate peroxidase, guaiacol peroxidase, POD, and CAT, and nonenzymic systems that act as free radical scavengers, such as ascorbic acid, thiols, and cysteine [28]. Superoxide dismutase converts superoxide radicals $\left(\mathrm{O}_{2}^{-}\right)$into $\mathrm{O}_{2}$ and $\mathrm{H}_{2} \mathrm{O}_{2}$ and acts in the first line of defense against oxidative stress [13]. In the present study, the activities of SOD in the leaves of $V$. faba were increased with increasing arsenate concentration, indicating that exposure to arsenate induced the formation of $\mathrm{O}_{2}^{-}$, which stimulated the biosynthesis of SOD. The situation is different, however, in the roots: In the 5 $\mu \mathrm{mol} / \mathrm{L}$ of arsenate treatment, the SOD activity of the roots was the highest, whereas in the $10 \mu \mathrm{mol} / \mathrm{L}$ of arsenate treatment, the SOD activity of the roots was significantly inhibited, possibly as a result of a more severe degree of toxicity, as shown by the aberrant coralloid root morphology. The decrease in SOD activity also could be a result of lipid peroxidation, because in the $10 \mu \mathrm{mol} / \mathrm{L}$ of arsenate treatment, the level of TBARS was significantly increased compared with the 5 $\mu \mathrm{mol} / \mathrm{L}$ of arsenate treatment, indicating severe membrane damage and inhibited cell processes, which could have led to the inhibition of SOD synthesis. This observation is in agreement with a previous study [8], which showed that the SOD activity of $H$. lanatus increased in response to low-concentration arsenate exposure but was inhibited in response to at high-concentration arsenate exposure. Catalase, which catalyzes the removal of $\mathrm{H}_{2} \mathrm{O}_{2}$ formed during the reaction catalyzed by SOD, is another component in the antioxidant enzymatic system in plant cells to control ROS [9,29]. In our experiments the patterns of CAT and SOD induction by arsenate were very similar, which underlined the complementary functions of these two enzymes.

Peroxidase is present in both prokaryotes and eukaryotes and is considered to play a role in antioxidant defense, which uses guaiacol or glutathione, pyridine nucleotides, and ascor-
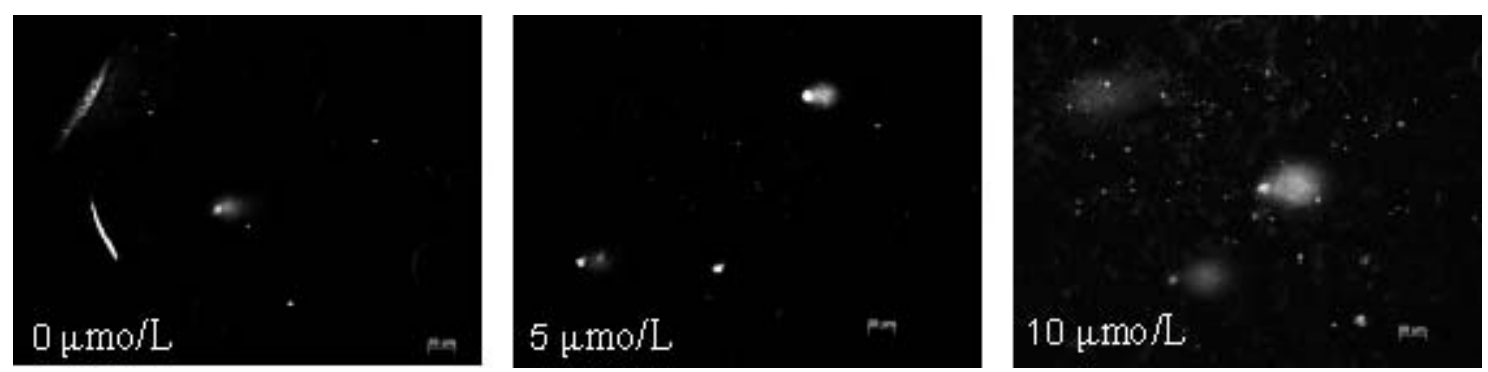

Fig. 7. Comet images of plant nuclei in the root of Vicia faba under arsenate treatments of 0,5 , and $10 \mu \mathrm{mol} / \mathrm{L}$. 
Table 3. DNA damage in roots of Vicia faba under different arsenate treatments ${ }^{a}$

\begin{tabular}{lrrrr}
\hline & \multicolumn{4}{c}{ Parameters of DNA damage } \\
\cline { 2 - 5 } $\begin{array}{l}\text { As concentration } \\
(\mu \mathrm{mol} / \mathrm{L})\end{array}$ & Tail length $^{\mathrm{b}}$ & \% tail DNA & TM & OTM \\
\hline 0 & $72.1 \pm 6.4$ & $53.9 \pm 6.4$ & $40.7 \pm 7.5$ & $25.0 \pm 3.9$ \\
5 & $85.9 \pm 8.6$ & $73.9 \pm 4.9$ & $65.5 \pm 10.8$ & $38.1 \pm 6.0$ \\
10 & $144.3 \pm 4.6$ & $91.0 \pm 1.0$ & $131.6 \pm 2.6$ & $68.9 \pm 0.1$ \\
\hline
\end{tabular}

${ }^{a}$ Values are presented as the mean \pm standard error. $\mathrm{TM}=$ tail moment; OTM $=$ olive tail moment.

${ }^{\mathrm{b}}$ Relative length in arbitrary units.

bate as the electron donors in the scavenging of $\mathrm{H}_{2} \mathrm{O}_{2}$ in the cell [30]. Peroxidase could play a role in alleviating oxidative stress induced by heavy metals or metalloids. In the present study, the POD activities of roots and leaves were increased under the $5 \mu \mathrm{mol} / \mathrm{L}$ of arsenate treatment, indicating that the accumulation of $\mathrm{H}_{2} \mathrm{O}_{2}$ in plant tissues may have stimulated the biosynthesis of POD. In the $10 \mu \mathrm{mol} / \mathrm{L}$ of treatment, however, POD, like SOD, was not increased in roots (see above).

Prolonged or high levels of exposure to heavy metals or metalloids can lead to a buildup of ROS, which in turn can damage cells through membrane peroxidation, loss of ions, protein cleavage, and most notably, DNA damage, leading to mutagenesis or cell death $[13,31]$. The results suggested that arsenate toxicity induced oxidative stress in the leaves and roots of $V$. faba. The Comet assay, which is widely used to evaluate the genotoxicity of chemicals in the environment [32], was employed to assess DNA damage induced by arsenate in $V$. faba. Both in leaves and in roots, the DNA damage increased with increasing arsenate concentration, indicating that arsenate-induced DNA damage in $V$. faba and the levels of DNA damage imposed by arsenate could be quantified by Comet assay.

In the leaves, the pattern of DNA damage was consistent with the increase in antioxidative enzyme capacities. In the roots, the enzyme capacities increased in the $5 \mu \mathrm{mol} / \mathrm{L}$ of arsenate treatment but decreased at the $10 \mu \mathrm{mol} / \mathrm{L}$ of arsenate treatment, which could have contributed to oxidative stress. The latter could relate to the strongly altered coralloid root structure at this treatment. Using Comet assay, Mancini et al. [33] showed that the hydrogen peroxide treatment caused DNA damage in tobacco plants, particularly the transgenic lines with deregulated levels of CAT and MnSOD. Another possible explanation for the low activity levels of antioxidative enzymes in the roots of the $10 \mu \mathrm{mol} / \mathrm{L}$ of arsenate treatment was the timing of the measurements. The present study analyzed plant materials exposed to arsenate for $14 \mathrm{~d}$. At this time, arsenate toxicity could already have inhibited the biosynthesis of the antioxidative enzymes, resulting in more accumulation of ROS. Hu et al. [34] reported that one of the mechanisms of As genotoxicity to human cells was to inhibit DNA repair in human cells by inducing ROS accumulation. In the present study, arsenate was found to induce oxidative stress in $V$. faba, which could be one of the mechanisms of DNA damage. Using the Comet assay of the human lung fibroblast cell line MRC5 , it was shown that As could induce DNA damage at the concentration, similar to the findings in the present study [4], indicating that the Comet assay using plant cells also could be used to assess the genotoxicity of chemicals.

In conclusion, our results suggest that arsenate toxicity causes oxidative stress and DNA damage in $V$. faba and that the DNA damage may be one of the results of the oxidative stress.
Acknowledgement-This study was supported by the Ministry of Science and Technology, China (2007CB407304), and the Young Scholars Fund of Beijing University of Chemical Technology, China (QN0603). We thank Henk Schat in the Vrije Universiteit for comments on the manuscript.

\section{REFERENCES}

1. Lombi E, Zhao F-J, Fuhrmann M, Ma LQ, McGrath SP. 2002. Arsenic distribution and speciation in the fronds of the hyperaccumulator Pteris vittata. New Phytol 156:195-203.

2. Mandal BK, Suzuki KT. 2002. Arsenic round the world: A review. Talanta 58:201-235.

3. Rhine ED, Garcia-Dominguez E, Phelps CD, Young LY. 2005. Environmental microbes can speciate and cycle arsenic. Environ Sci Technol 39:9569-9573.

4. Mourón SA, Golijow CD, Dulout FN. 2001. DNA damage by cadmium and arsenic salts assessed by the single-cell gel electrophoresis assay. Mutat Res 498:47-55.

5. Hughes MF. 2002. Arsenic toxicity and potential mechanisms of action. Toxicol Lett 133:1-16.

6. Kitchin KT. 2001. Recent advances in arsenic carcinogenesis: Modes of action, animal model systems, and methylated arsenic metabolites. Toxicol Appl Pharmacol 172:249-261.

7. Meharg AA, Hartley-Whitaker J. 2002. Arsenic uptake and metabolism in arsenic resistant and nonresistant plant species. New Phytol 154:29-43.

8. Hartley-Whitaker J, Ainsworth G, Meharg AA. 2001. Copperand arsenate-induced oxidative stress in Holcus lanatus L. clones with differential sensitivity. Plant Cell Environ 24:713-722.

9. Aravind P, Prasad MN. 2003. Zinc alleviates cadmium-induced oxidative stress in Ceratophyllum demersum L.: A free-floating freshwater macrophyte. Plant Physiol Biochem 41:391-397.

10. Geng CN, Zhu YG, Hu Y, Williams P, Meharg AA. 2006. Arsenate causes differential acute toxicity to two P-deprived genotypes of rice seedlings (Oryza sativa L.). Plant Soil 279:297-306.

11. Singh N, Ma LQ, Srivastava M, Rathinasabapathi B. 2006. Metabolic adaptations to arsenic-induced oxidative stress in Pteris vittata $\mathrm{L}$ and Pteris ensiformis L. Plant Sci 170:274-282.

12. Gichner T. 2003. DNA damage induced by indirect and direct acting mutagens in catalase-deficient transgenic tobacco: Cellular and acellular Comet assays. Mutat Res 535:187-193.

13. Mittler R. 2002. Oxidative stress, antioxidants, and stress tolerance. Trends Plant Sci 7:405-410.

14. Duan GL, Zhu Y-G, Tong Y-P, Cai C, Kneer R. 2005. Characterization of arsenate reductase in the extract of roots and fronds of Chinese brake fern, an arsenic hyperaccumulator. Plant Physiol 138:461-469.

15. Hoagland DR, Arnon DI. 1938. The water culture method for growing plants without soil. California Agricultural Experiment Station Circular 347:1-39.

16. Carbonell AA, Aarabi MA, DeLaune RD, Gambrell RP, Patrick WH Jr. 1998. Arsenic in wetland vegetation: Availability, phytotoxicity, uptake, and effects on plant growth and nutrition. Sci Total Environ 217:189-199.

17. Verma S, Dubey RS. 2003. Lead toxicity induces lipid peroxidation and alters the activities of antioxidant enzymes in growing rice plants. Plant Sci 164:645-655.

18. Lagrimini LM. 1991. Wound-induced deposition of polyphenols in transgenic plants overexpressing peroxidase. Plant Physiol 96: 577-583.

19. Stewart RRC, Bewley JD. 1980. Lipid peroxidation associated with accelerated aging of soybean areas. Plant Physiol 65:245248. 
20. Navarrete MH, Carrera P, Miguel M, Torre C. 1997. A fast comet assay variant for solid tissue cells. The assessment of DNA damage in higher plants. Mutat Res 389:271-277.

21. Gichner T, Ptacek O, Stavreva DA, Wagner ED, Plewa MJ. 2000. A comparison of DNA repair using the comet assay in tobacco seedlings after exposure to alkylating agents or ionizing radiation. Mutat Res 470:1-9.

22. Lin AJ, Zhu Y-G, Tong YP, Geng CN. 2005. Evaluation of genotoxicity of combined pollution by cadmium and atrazine. Bull Environ Contam Toxicol 74:589-596.

23. Konca K, Lankoff A, Banasik A, Lisowska H, Kuszewski T, Gozdz S, Koza Z, Wojcik A. 2003. A cross-platform public domain PC image-analysis program for the comet assay. Mutat Res 534:15-20.

24. Payne RW, ed. 2002. The Guide to GenStat Release 6.1-Part 1: Syntax and Data Management. GenStat Committee, VSN International, Hemel Hempstead, UK.

25. Kabata-Pendias A, Pendias H. 1992. Trace Elements in Soils and Plants. CRC, London, UK.

26. Palma JM, Sandalio LM, Corpas FJ, Romero-Puertas MC, MaCarthy I, Rio LA. 2002. Plant proteases, protein degradation and oxidative stress: Role of peroxisomes. Plant Physiol Biochem 40:521-530.
27. Mascher R, Lippmann B, Holzinger S, Bergmann H. 2002. Arsenate toxicity: Effects on oxidative stress response molecules and enzymes in red clover plants. Plant Sci 163:961-969.

28. Sinha S, Saxena R, Singh S. 2005. Chromium induced lipid peroxidation in the plants of Pistia stratiotes L.: Role of antioxidants and antioxidant enzymes. Chemosphere 58:595-604.

29. Gupta R, Kannan GM, Sharma M, Flora SJS. 2005. Therapeutic effects of Moringa oleifera on arsenic-induced toxicity in rats. Environ Toxicol Pharmacol 20:456-464.

30. Prasad TK, Anderson MD, Stewart CR. 1995. Localization and characterization of peroxidases in the mitochondria of chillingacclimated maize seedlings. Plant Physiol 108:1597-1605.

31. Wilson DM, Sofinowski TM, McNeill DR. 2003. Repair mechanisms for oxidative DNA damage. Front Biosci 8:963-981.

32. Koppen G, Verschaeve L. 1996. The alkaline Comet test on plant cells: A new genotoxicity test for DNA strand breaks in Vicia faba root cell. Mutat Res 360:193-200.

33. Mancini A, Buschini A, Restivo FM, Rossi C, Poli P. 2006. Oxidative stress as DNA damage in different transgenic tobacco plants. Plant Sci 170:845-852.

34. Hu Y, Su L, Snow Elizabeth T. 1998. Arsenic toxicity is enzyme specific and its affects on ligation are not caused by the direct inhibition of DNA repair enzymes. Mutat Res 408:203-218. 